\title{
NILAI-NILAI DIDAKTIS DALAM NOVEL KUTUB TAK BERSALJU KARYA AMIKA AN
}

\author{
Dahlia Delfitri ${ }^{1 *}$, Herry N Hidayat ${ }^{2}$, Yerri Satria Putra ${ }^{3}$ \\ dahliadelfitri@gmail.com* \\ Fakultas Ilmu Budaya Universitas Andalas ${ }^{1,2,3}$
}

\begin{abstract}
ABSTRAK
Tulisan ini merupakan deskripsi nilai-nilai didaktis yang ada dalam novel Kutub Tak Bersalju. Nilai-nilai didaktis diperoleh melalui analisis menggunakan teori struktural, yakni unsur intrinsik. Melalui unsur intrinsik tersebut dapat ditemukan nilai-nilai didaktis yang terdapat dalam novel Kutub Tak Bersalju. Hasilnya, nilai-nilai didaktis dalam novel Kutub Tak Bersalju antara lain: nilai tauhid yaitu nilai keimanan dan ketakwaan, kepedulian dan kasih sayang, kegigihan keuletan, kerja keras dan mandiri, kesabaran, cinta damai, dan menghargai prestasi.
\end{abstract}

Kata-kata kunci: Novel, Kutub Tak Bersalju, Nilai-Nilai Didaktis, Unsur Intrinsik.

\section{DIDACTIC VALUES IN KUTUB TAK BERSALJU NOVEL}

\section{ABSTRACT}

This paper is a description of the didactic values that exist in the novel Kutub Tak Bersalju. Didactic values are obtained through analysis using structural theory, namely the intrinsic element. Through these intrinsic elements, didactic values can be found in the novel Kutub Tak Bersalju. As a result, the didactic values in the novel Kutub Tak Bersalju include monotheism, namely the value of faith and piety, care and compassion, tenacity, hard work and independence, patience, love of peace, and respect for achievement.

Keywords: Novel, Kutub Tak Bersalju, Didactic Value, Intrinsic Aspect

Jurnal Elektronik WACANA ETNIK - Vol 9 No 2, 2020, (78 - 92) p ISSN 2089-8746, e ISSN 2302-7142

Submit: Juli 2020. Diterima: September 2020. Publikasi: Oktober 2020. 


\section{PENGANTAR}

Karya sastra merupakan sebuah karya tulis berupa fiksi. Karya sastra berasal dari sebuah hasil imajinatif seorang pengarang yang mengandung unsur-unsur estetika. Pada karya sastra pemilihan kata dan pemilihan alur cerita, membuat pembaca tertarik untuk membacanya Salah satu bentuk karya sastra adalah novel. Novel mengungkapkan suatu konsentrasi kehidupan pada suatu saat tegang, dan memusatkan kehidupan yang tegas (Semi, 1984: 24). Novel memberikan sebuah bentuk penceritaan tentang kehidupan seseorang yang berada dalam lingkungan keluarga atau masyarakat. Sebagai pencerminan dari realitas kehidupan masyarakat, novel yang memuat suatu peristiwa yang terjadi dengan tokoh sebagai pelaku. Dalam kehidupan masyarakat novel memiliki fungsi untuk menghibur dan mendidik. Pada novel mengandung nilai-nilai pendidikan (didaktis) karena pada dasarnya bersifat persuasif, yaitu dapat mempengaruhi pembaca untuk meneladani atau mengikuti hal-hal tingkah laku tokoh yang tercermin dalam cerita.

Didaktis menurut Kamus Besar Bahasa Indonesia (KBBI) berarti bersifat mendidik. Mendidik merupakan memelihara dan memberi latihan (ajaran, tuntunan, pimpinan) mengenai akhlak dan kecerdasan pikiran. Sementara itu pendidikan adalah proses pengubahan sikap dan tata laku seseorang atau sekelompok orang dalam usaha mendewasakan manusia melalui upaya pengajaran dan pelatihan; proses, cara, perbuatan mendidik. Selanjutnya nilai berarti sifat-sifat, hal-hal yang penting atau berguna bagi kemanusiaan (KBBI, 2002:326). Sementara itu, Bertens (2001: 139) mengatakan, bahwa nilai adalah sesuatu yang menarik, sesuatu yang dicari, yang menyenangkan, yang diinginkan manusia, singkatnya sesuatu yang baik. Nilai merupakan sesuatu yang diinginkan manusia, bersifat normatif, yaitu keharusan yang diwujudkan dalam tingkah laku kehidupan manusia. Jadi, nilai didaktis merupakan sesuatu yang penting dalam hal yang bersifat mendidik dan memberikan tuntunan mengenai tingkah laku kesopanan dan kecerdasan dalam berpikir.

Menurut Muslich (dalam Sepniyantika, 2011: 150) pendidikan atau didaktis dibentuk oleh beberapa pilar yang saling berkaitan. Pilar-pilar tersebut adalah nilai-nilai pendidikan yang luhur universal, yaitu, religius, tanggung jawab, kerja keras dan pantang menyerah, kasih sayang, kejujuran dan tanggung jawab, baik rendah hati, kepedulian, keuletan, dan percaya diri.

Salah satu karya sastra yang berisi tentang nilai-nilai didaktis adalah novel Kutub Tak Bersalju karya Amika An. Novel Kutub Tak Bersalju banyak mengandung nilai-nilai pendidikan yang nantinya akan menjadi teladan bagi pembacanya. Novel Kutub Tak Bersalju merupakan novel pertama dari penulis bernama Amika An. Amika An merupakan nama pena dari Rahmi Safitri Riska. Ia lahir di Simpang Tanjuang Nan IV. Novel pertamanya terbit pada tahun 2013. Novel tersebut sudah dicetak ulang sebanyak empat kali yaitu, cetakan pertama pada bulan Juni 2013, cetakan kedua pada bulan Oktober 2013, cetakan ketiga pada bulan Januari 2014 dan cetakan keempat pada bulan Juni 2014.

Berdasarkan hal tersebut di atas alasan peneliti mengambil objek nilai-nilai didaktis dalam novel yang berjudul Kutub Tak Bersalju karya Amika An. Karena novel ini mampu memberikan motivasi bagi pembaca dan novel ini terinspirasi dari kisah yang disampaikan bukan hanya sebagai karya seni, tetapi tentang proses pendidikan 
demi mewujudkan cita-citanya, selain banyaknya nilai-nilai didaktis yang terdapat di dalamnya. Dengan demikian dapat menambah wawasan mengenai nilai-nilai pendidikan, di antaranya berupa nilai kesabaran, ketakwaan, nilai kasih sayang, saling menolong, kepedulian dan didikan yang baik dari keluarga apalagi pada tokoh utama dari kecil ia sudah memiliki nilai-nilai didaktis.

\section{KERANGKA TEORI DAN METODE}

Untuk menentukan nilai-nilai didaktis yang terdapat dalam novel Kutub Tak Bersalju karya Amika An maka peneliti menggunakan pendekatan struktural. Di antaranya unsur intrinsik dan unsur ekstrinsik. Salah satu di antara unsur intrinsik berupa tokoh dan penokohan, plot, latar, tema, dan amanat. Tokoh dan penokohan melalui tema cerita, yang sekaligus dikonkretkan dalam amanat. Amanat merupakan ajaran moral atau pesan yang disampaikan dalam cerita dan ditujukan untuk pembacanya. Secara tidak langsung pembaca dapat mengambil pelajaran dari amanat yang disampaikan oleh pengarang. Untuk menemukan tema, dibutuhkan membaca secara cermat atau tekun agar dapat menemukan tema. Di samping itu, tema dapat juga terungkap dari dialog tokoh, terutama lewat tokoh utama dan penokohan.

Unsur intrinsik merupakan unsur-unsur yang membentuk karya sastra. Adapun unsur-unsur tersebut meliputi peristiwa, cerita, tokoh, penokohan, plot atau alur, latar, tema, sudut pandang, dan sebagainya (Nurgiyantoro, 1995: 23).

Pada istilah tokoh menunjukkan pada perilaku cerita, sedangkan penokohan adalah gambaran yang jelas tentang seseorang yang ada dalam sebuah cerita. Tokoh merupakan salah satu unsur penting dalam sebuah karya. Kehadiran tokoh membuat karya mudah dipahami. Tokoh adalah individu rekaan yang mengalami peristiwa atau perlakuan dalam berbagai peristiwa cerita, sedangkan penokohan adalah penyajian watak tokoh dan penciptaan citra tokoh (Sudjiman,1991: 16).

Tokoh cerita menempati posisi strategis sebagai pembawa dan penyampaian pesan, amanat, moral atau sesuatu yang sengaja ingin disampaikan kepada pembaca (Nurgiyantoro, 1995: 167). Tokoh dapat dibedakan menjadi dua jenis yaitu: tokoh utama dan tokoh tambahan. Tokoh utama adalah tokoh yang diutamakan penceritaannya. Ia merupakan tokoh yang paling banyak diceritakan, baik sebagai pelaku maupun yang dikenai kejadian. Sedangkan tokoh tambahan yaitu tokoh dalam cerita yang sering dimunculkan dalam keseluruhan cerita lebih sedikit, tidak dipentingkan, dan kehadirannya hanya jika ada keterkaitannya dengan tokoh utama (Nurgiyantoro, 1995:177).

Menurut Bambang Daroeso, nilai adalah suatu kualitas atau penghargaan terhadap sesuatu, yang menjadi dasar penentu tingkah laku seseorang. Menurut Darji Darmodiharjo (dalam Herimanto,2016: 127) nilai adalah kualitas atau keadaan yang bermanfaat bagi manusia baik lahir ataupu batin. Sesuatu yang dianggap bernilai adalah apabila sesuatu itu memiliki sifat sebagai berikut: Menyenangkan, berguna, memuaskan, menguntungkan, menarik, keyakinan.

Pendidikan tidak hanya melingkupi bidang pengajaran di sekolah-sekolah atau di rumah, tetapi juga meliputi segala yang dapat mempengaruhi kebaikan jiwa manusia sejak kecil hingga dewasa dan hingga menjadi 
orang tua. Di Minangkabau selain pendidikan di rumah dan di sekolah, nilai pendidikan juga diadakan di surau. Surau adalah tempat belajar agama bagi anak-anak, ilmu yang didapat di surau tidak hanya ilmu agama saja, tetapi juga ilmu yang dibutuhkan dalam kehidupan sehari-hari seperti pengetahuan, sopan santun, kemandirian dan sebagainya. Menurut Hanani (2002:25-28), Surau merupakan pusat kegiatan anak-anak muda dalam menuntut ilmu agama dan bermacam-macam pengetahuan praktis serta kebudayaan, seperti belajar tarikat, berniaga, dan pencak silat. Sistem pendidikan dalam masyarakat Minangkabau, surau mempunyai dua makna bagi kehidupan orang Minangkabau. Pertama, bermalam berarti menjadi tempat tidur dan tempat beristirahat di malam hari. Kedua, surau sebagai tempat belajar dan menimba ilmu untuk bekal hidup. Sistem pendidikan yang dikembangkan yaitu sistem halaqah yaitu para murid duduk bersila dan berkelompok-berkelompok mendengarkan keterangan dari guru, tugas utama guru adalah sebagai imam yang memberikan contoh teladan pada murid dan masyarakat luas.

Metode yang digunakan dalam penelitian ini adalah metode deskriptif analisis yaitu dengan cara mendeskripsikan fakta-fakta yang kemudian disusul dengan analisis (Ratna, 2004:53). Cara kerja dari metode analisis deskriptif ini adalah data yang diperoleh dari kata-kata tertulis, dianalisis dengan menggunakan pendekatan struktural. Data yang diperoleh dalam penelitian ini menggunakan studi kepustakaan dan membaca karya sastra berulang-ulang kali dengan teliti agar mudah dipahami, maka data yang didapat terbagi atas data primer dan sekunder. Data primer ditelusuri lewat sumber data pada novel Kutub Tak Bersalju. Cara memperolehnya dengan membaca novel secara teliti, mengumpulkan data dan memilah data sesuai dengan nilai-nilai didaktis yang terdapat dalam novel Kutub Tak Bersalju. Data primer penelitian ini adalah deskripsi dan dialog yang membangun unsur tokoh dan penokohan, alur, latar, tema dan amanat. Data sekunder berupa buku-buku referensi yang terkait berhubungan dengan objek ini. Analisis data dilakukan dengan cara menganalisis objek dengan pendekatan struktural dan menemukan nilai-nilai didaktis, yang terdapat dalam novel Kutub Tak Bersalju karya Amika An sehingga pada akhirnya dapat ditarik kesimpulan dari analisis yang dilakukan.

\section{HASIL DAN PEMBAHASAN}

Menurut Muslich (dalam Sepniyantika, 2011: 150) pendidikan atau didaktis dibentuk oleh beberapa pilar yang saling berkaitan. Pilar-pilar tersebut adalah nilai-nilai pendidikan yang luhur universal, yaitu, religius, tanggung jawab, kerja keras dan pantang menyerah, kasih sayang, kejujuran dan tanggung jawab, baik rendah hati, kepedulian, keuletan, dan percaya diri. Di dalam novel Kutub Tak Bersalju terdapat beberapa nilai-nilai didaktis sebagai berikut.

\section{NILAI TAUHID}

Tauhid dilihat dari segi etimologis yaitu berarti “Keesaan Allah", mentauhidkan berarti mengakui keesaan Allah, mengesakan Allah. "Mempercayai bahwa Allah SWT adalah satu-satunya pencipta, pemelihara, dan mengatur Alam Semesta. Tauhid merupakan awal dari iman dan takwa. Iman atau keimanan secara etimologis berarti kepercayaan atau keyakinan, pengakuan dan pembenaran oleh hati tentang bahwa tiada tuhan melainkan Allah SWT. Keimanan tersebut diwujudkan dalam ucapan dan perbuatan, yaitu seluruh kegiatan dan tingkah laku, baik bicara, kerja, maupun karya harus sesuai dengan ketentuan Allah SWT. Sedangkan ketakwaan merupakan tindak lanjut dari 
keimanan pada tataran praktiknya dalam kehidupan sehari-hari (Izharman, 2014:104-109). Dalam novel Kutub Tak Bersalju terdapat nilai-nilai tauhid yaitu nilai keimanan dan ketakwaan. Nilai tersebut disampaikan melalui tindakan dan perilaku tokoh seperti tokoh Buyuang dan teman-temannya. Ini terdapat pada kutipan di bawah ini.

"Pada waktu-waktu sholat mereka menghentikan segala bentuk aktivitas, dan menunaikan sholat berjamaah di bagian pojok cafe yang mereka namakan Musholla Mini.” (Amika An, 2014:44).

Berdasarkan kutipan di atas, menggambarkan bahwa tokoh Buyuang dan teman-temannya memiliki nilai keimanan dan ketakwaan, ini terlihat dari tindakan yang dilakukan oleh tokoh Buyuang dalam melakukan kegiatannya sehari-hari yang ia lakukan ketika datangnya waktu salat mereka menghentikan semua aktivitasnya dan segera melaksanakan perintah Allah. Sementara itu, nilai keimanan dan ketakwaan disampaikan melalui tindakan yang dilakukan oleh tokoh Fatwa, seperti dalam setiap salatnya ia selalu berdoa kepada sang Kholiq untuk selalu meminta pertolongan-Nya agar ia bisa menjadi pemenang lomba hafiz.

Selain itu, tokoh Fatwa selalu bersyukur dan memohon kepada Tuhan Yang Maha Esa untuk semua kemudahan dalam perjuangan menghafal Alquran yang diberikan Allah kepadanya. Seperti pada kutipan di bawah ini:

"Ya Allah, atas kuasamu aku bisa menginjakkan kaki di sini, atas izinmu aku bisa selamat sampai ke tempat ini, atas kemurahanmu aku bisa mengukir prestasi, atas segala yang tidak pernah aku bayangkan sebelumnya, Engkau memberiku sebuah kesempatan yang tidak semua orang bisa memiliknya. Terima kasih ya Allah. Besok aku akan berperang, dan hingga malam ini aku terus berjuang membulatkan peluru berbahan dasar ayat-ayatmu"(Amika An, 2014:204).

Dari kutipan di atas pengarang menggambarkan bahwa tokoh Fatwa sebagai tokoh utama mencerminkan tokoh yang taat dan patuh pada agama. Keimanan dan ketakwaan ini dicerminkan pada tokoh Fatwa yang meyakinkan adanya Allah SWT. Setiap apa yang dikerjakan ia selalu berdoa kepada Tuhan Yang Maha Kuasa, ia selalu ingat akan ayat-ayat Allah kapan pun itu. Tokoh Fatwa selalu yakin dengan pertolongan Allah karena dengan kekurangan yang ia memiliki tetapi ia memiliki keluarga yang sangat peduli kepadanya.

Nilai tauhid juga disampaikan melalui tindakan yang dilakukan oleh tokoh Mak tuo yaitu nilai keimanan dan ketakwaan. Hal ini terlihat ketika Mak Tuo membicarakan tentang orang-orang yang mengenal ayat-ayat Allah. Seperti yang terdapat dalam kutipan berikut:

"Fatwa jangan berkecil hati sayang. Yakinlah, ketekunan itu akan ada hasilnya. Lanjutkan mempelajari apa yang telah kamu ketahui sebelumnya. Jangan sampai lupa, dan tingkatkan semampumu, Nak! Fatwa, sejatinya kehidupan ini hanya sesaat. Kehidupan akhiratlah yang kekal selama-lamanya. Sebenarnya Allah tidak menginginkan umatnya menjadi sarjana. Percuma mempunyai gelar akademis, jika tidak kenal dengan ayat-ayat Allah. Lebih baik kita menjadi orang yang biasa-biasa saja, tapi luar biasa dalam hal Agama. Fatwa tahu penghargaan Allah kepada orang yang hafal alquran.”(Amika An, 2014: 158).

Kutipan di atas pengarang menggambarkan bahwa Mak Tuo memiliki nilai-nilai keimanan dan ketakwaan. Ini terlihat ketika Mak Tuo yang tidak lupa memberi nasehat kepada Fatwa. Mak Tuo mengingatkan kepada tokoh 
Fatwa bahwa didunia ini hidup hanya sementara kehidupan akhiratlah yang kekal selamanya. Mak Tuo mengatakan percuma sekolah tinggi kalau tidak mengenal ayat-ayat Allah, jadilah orang yang menjadi penghafal alquran

Selain tokoh Fatwa, nilai tauhid juga disampaikan melalui tokoh Da Tofik yang memiliki nilai keimanan dan ketakwaan. Nilai tersebut terlihat dari tindakan tokoh Da Tofik dari kecil ia telah ditanam nilai-nilai agama oleh orang tuanya sampai sekarang nila-nilai agama yang ditanamkan orang tuanya sangat ia amalkan seperti ia taat beribadah, salat tepat waktu sebelum datang azan berkumandang, ia telah berada di dalam masjid. Seperti yang terdapat dalam kutipan berikut:

"Beduk maghrib merampas senja. Suara Da Topik bergema di udara. Sifatnya tidak berbeda jauh dengan Da Buyuang. Beruntung perempuan yang menjadi pelabuhan hati uda nanti. Orangnya santun dan cerdas, barang kali bisa menjadi anggota DPR. Dia besar dari keluarga biasa. Ayahnya petani dan ibunya juga petani. Nilai-nilai agama yang ditanamkan orang tuanya sangat di amalkan. Sangat kontras dengan laki-laki seusianya yang banyak menghabiskan waktu dengan hal-hal yang tidak bermanfaat" (Amika An, 2014: 197).

Berdasarkan kutipan di atas terlihat bahwa tindakan yang dilakukan oleh tokoh Da Topik merupakan nilai tauhid ini terlihat dari kegiatan yang dilakukan oleh tokoh Da Topik yang melakukan perintah Allah dan meninggal larangan Allah karena tokoh Da topik selalu mengamalkan nilai-nilai agama yang diajarkan oleh orang tuanya. Nilai ketakwaan juga disampaikan melalui tokoh anak-anak surau. Seperti yang terdapat pada kutipan berikut.

"Rekaman ceramah da'i sejuta umat, Zainudin MZ seperti menghinoptis anak-anak untuk meninggalkan permainan mereka. Baru saja kaset diputar, kelereng, gambar, sibis akan kembali kesaku pemiliknya masing-masing. Mereka akan bergegas mencari mukenah, sarung, peci dan jus amma. Lalu berwudhu dan berlomba menuju masjid.”(Amika An, 2014: 97).

Kutipan di atas terlihat bahwa tindakan yang dilakukan oleh anak-anak surau merupakan nilai ketakwaan ini tergambar pada tokoh anak-anak yang meninggalkan kegiatannya setelah mendengarkan rekaman ceramah. Anakanak tersebut berbondong-bondong pergi ke masjid dan langsung mengambil wudu untuk melaksakan kewajibannya belajar agama ke masjid. Nilai keimanan dan ketakwaan disampaikan melalui tokoh Abak.

Berdasarkan uraian di atas, nilai-nilai didaktis tentang nilai tauhid terdapat pada tokoh Fatwa yang mencerminkan tokoh yang mempunyai nilai keimanan dan ketakawaan. Selain itu, tokoh Buyuang juga memiliki nilai-nilai keimanan dan ketakwaan dari kecil ia telah mengamal ilmu-ilmu agama begitu juga dengan Da Taufik. Selain itu nilai-nilai keimanan dan ketakwaan juga terdapat pada kokoh Abak, Mak Tuo dan anak-anak di masjid.

\section{KEGIGIHAN DAN KEULETAN}

Nilai kegigihan adalah keteguhan memegang pendapat atau mempertahankan pendirian. Keuletan adalah tidak mudah putus asa yang disertai dengan kemauan keras dalam berusaha mencapai tujuan dan cita-cita (KBBI edisi kelima). Pada novel Kutub Tak Bersalju terdapat nilai kegigihan dan keuletan. Nilai tersebut disampaikan melalui karakter, tindakan perilaku tokoh seperti tokoh Fatwa yang memiliki nilai kegigihan dan keuletan dalam menghafal ayat Al Qur'an. Seperti pada kutipan di bawah ini. 
"Fatwa berjuang menghafal setengah jus lagi dalam waktu 3 bulan. Ambisi yang begitu kuat mencambuknya untuk terus menghafal tanpa memperdulikan hambatan. Pagi, siang, malam digunakannya untuk mengisi memori dengan ayat-ayat Allah. Ia sampai tertidur di pinggir danau namun rasa kantuk berusaha dilawannya sekuat tenaga. Setiap kali matanya terasa terkantuk, diambilnya air lalu dibasahi wajahnya agar seperti semula, begitu seterusnya, hingga yang menghentikan usahanya adalah waktu sholat dan makan saja" (Amika An, 2014:187).

"Dia ingin melanjutkan perjuangannya yang masih mentah. Hafalan shalatnya belum sempurna. Belajar iqra' belum tamat. Bagaimana ia bisa menuruti keinginannya untuk bisa membaca Alqur'an? Dia ingin menjadi qoriah yang baik, walau dengan keterbatasannya” ( Amika An 154).

Berdasarkan kutipan di atas, bahwa tindakan yang dilakukan oleh tokoh Fatwa merupakan nilai kegigihan dan keuletan. Nilai tersebut terlihat dari usaha yang dilakukan oleh tokoh Fatwa dalam menghafal ayat Al Qur'an. Setiap waktu ia selalu belajar tanpa kenal lelah hanya waktu salat dan makan yang mampu membuatnya istirahat dalam belajarnya. Fatwa selalu gigih untuk bisa menjadi qoriah yang baik walaupun ia belum hafal salatnya dan belajar iqra' belum tamat tetapi ia tetap berusa keras untuk lanjut menjadi seorang qoriah. Nilai kegigihan dan keuletan juga disampaikan melalui tokoh Mak Tuo. Nilai tersebut dilihat dari kegiatan tokoh Mak Tuo mengajar anak-anak di surau agar anak-anak bisa menjadi orang disiplin dan tekun kepada guru-guru yang mengajarnya dan terus belajar. Seperti yang terdapat dalam kutipan berikut:

"Mak tuo adalah guru teladan yang sehari-harinya berjalan kaki menuju masjid tempatnya mengajar. Beliau adalah guru senior terpaforit di masjid ini. Tegas dalam soal agama, tapi tidak tegang dalam hal pemakaian cara. Beliau punya cara tersendiri bagaiaman menarik perhatian anak-anak. Sampai jam setengah enam pun mereka berlama-lama mendengar cerita Mak tuo. Tak akan ada yang menandingi keikhlasan perempuan baik ini rasanya" ( Amika An,2014: 97).

\section{KERJA KERAS DAN MANDIRI}

Kerja keras merupakan sikap yang tidak bermalas-malasan yang menunjukkan upaya bersungguh-sungguh dalam melakukan sesuatu. Mandiri merupakan tidak bergantung pada orang lain. Dalam novel Kutub Tak Bersalju terdapat nilai kerja keras dan mandiri. Nilai kerja keras dan mandiri disampaikan melalui tokoh Buyuang dan para teman-temannya. Seperti yang terdapat pada kutipan di bawah ini.

"Kedekatan nenek dan Buyuang terus berlanjut hingga usianya beranjak remaja. Buyuang dan dua orang bujang-bujang tangguang lainnya sering menjadikan nenek sebagai konsulatan bisnis. Sejak kelas 3 SD mereka sudah mendalami ilmu marketing plan dari nenek. Hingga karir mereka meroket di kancah perdagangan garam lokal. Rat-rata anak di daerah ini tidak diajarkan hidup manja dari kecil mereka dididik bagaimana memaknai selembar uang, tidak gampang mendapatkannya. Ke sekolah, tak hanya belajar. Jika bagi sebagian orang, sekolah adalah bermain sambil belajar, maka bagi mereka adalah berdagang sambil belajar"(Amika An, 2014:37).

Dari kutipan di atas pengarang menggambarkan tokoh Buyuang dan kawan-kawannya memiliki nilai pekerja keras dan mandiri. Sejak kecil mereka telah diajar hidup mandiri, dimulai ketika mereka kecil yang menjadikan nenek sebagai panutannya. Dari kecil tokoh Buyuang dan teman-temanya sudah mulai memiliki nilai kerja keras dan mandiri, dari kecil mereka mulai berdagang garam. Kerja keras mereka pun tidak menghianati hasil, buktinya mereka bisa sukses dibidang perdagangan. Nilai kerja keras dan mandiri disampaikan melalui Tokoh nenek. Sejak kecil 
nenek telah bekerja keras dan mandiri demi membantu keluarganya karena nenek sebagai tulang punggung keluarga demi membatu adik-adiknya. Seperti yang terdapat dalam kutipan berikut.

"Nenek, seorang perempuan berpendirian baja. Kerja keras tergambar jelas dari raut wajahnya yang tegas dan pantang menyerah. Kejamnya hidup yang mencetak kepribadian seperti itu. Anak perempuan pertama dengan lima adik yang bersusun paku setelahnya, menjadi naluri keibuanya sudah tumbuh sejak kecil. Mungkin saja beliau tak begitu menikmati masa-masa remajanya, karena harus menjalankan multi peran dalam keluarga." (Amika An, 2014: 31).

Selain tokoh nenek yang dijelaskan di atas, nilai kerja keras dan mandiri juga disampaikan melalui tokoh Abak ini tenggambar dari sikap pekerja keras tokoh Abak dari kecil Abak telah diajarkan bekerja. Abak terus bekerja sederas apapun hujan Abak harus tetap kepasar karena tanggung jawab Abak banyak, Abak harus terus berusaha dan bekerja keras untuk memenuhi kebutuhan. Seperti yang tredapat berikut.

"Tidak sanggup ke mana-mana. Namun itu tidak berlaku bagi Abak. Sederas apapun hujan, beliau tetap ke pasar. Tanggung jawab yang besar sebagai seorang ayah benar- benar tertanam dalam diri pada diri anak bungsu dari empat bersaudara itu. dari kecil beliau terbiasa dengan hiruk pikuk pasar" (Amika An. 2014: 184).

Berdasarkan kutipan di atas, bahwa tindakan yang dilakukan oleh tokoh Abak merupakan nilai kerja keras dan mandiri. Nilai tersebut terlihat dari usaha yang dilakukan oleh tokoh Abak, Abak seorang yang bekerja keras dan sebagai tulang punggung keluarga karena Abak dari kecil sudah belajar mandiri dan telah bekerja keras. Nilai kerja keras juga disampaikan melalui tokoh Mak Uncu juga memiliki nilai kerja keras dan mandiri, sebagaimana yang terdapat pada kutipan di bawah ini.

"Mak Uncu berarti mamak paling bungsu adalah mamak termuda di antara mamak-mamaknya yang lain. Tapi kematangan emosinya dalam menyikapi permasalahan, beliau tidak terlihat seperti anak muda kebanyakan. Bahkan dalam rapat-rapat kecil keluarga dan rapat-rapat pemuda beliau terkenal sangat kritis. Walaupun anak bungsu dari kecil tak pernah diajarkan hidup manja. Sakit hidup harus dinikmati begitu prinsip hidupnya" (Amika An, 2014:57).

Berdasarkan kutipan di atas, tindakan yang dilakukan oleh tokoh Mak Uncu merupakan nilai kerja keras dan mandiri. Nilai tersebut dilihat dari kehidupan tokoh Mak Uncu semasa ia kecil ia tidak dimanjakan namun diajarkan hidup mandiri tidak seperti pada anak-anak pada umumnya.

\section{NILAI KEPEDULIAN DAN KASIH SAYANG}

Dalam novel Kutub Tak Bersalju terdapat nilai-nilai kepedulian dan kasih sayang. Peduli merupakan nilai yang sangat dibutuhkan dalam kehidupan sosial. Manusia tidak bisa hidup sendiri. Oleh sebab itu, dia akan membutuhkan bantuan orang lain atau sosial dan diri sendiri. Sementara itu kasih sayang merupakan kata kasih dan sayang tidak hanya berhubungan dengan urusan asmara antara laki-laki dan perempuan. Akan tetapi, bersifat umum, sehingga hal ini dapat terjadi dalam lingkungan sosial, seperti kepada orang tua atau keluarga, sahabat, binatang, tumbuhan dan lain-lain. Makna kasih sayang mengajari tentang cara menghargai dan menghormati keluarga dan orang lain dalam kehidupan sehari-hari. Hal ini akan dibuktikan dengan menghilangkan rasa benci dan dendam bila terjadi pertikaian. Dalam KBBI kasih sayang berarti cinta atau belas kasihan (2002:631). 
Dalam novel Kutub Tak Bersalju nilai kepedulian dan kasih sayang disampaikan melalui tindakan yang dilakukan tokoh seperti tokoh Nenek. Tokoh nenek diceritakan seorang tokoh yang suka bercerita tentang ceritacerita rakyat yang berkembang di lingkungan masyarakat sekitar. Di antaranya seperti "Anak Dewa", "Batu Ampa dan Batu Jawi”, "Misteri Danau Kembar". Cerita tersebut pada umumnya berisi tentang cerita-cerita rakyat yang disampaikan oleh seorang tokoh Nenek kepada cucu-cucunya, salah satunya adalah tokoh Fatwa. Dalam cerita ini tokoh nenek memang sangat suka bercerita.

Cara mendidik tokoh nenek kepada cucunya yaitu dengan cara bercerita. Dengan begitu sang anak menjadi paham dan mengerti tanpa harus memarahi cucu tersebut. Salah satunya pada tokoh nenek yang selalu bercerita pada Fatwa tentang kisah-kisah seorang anak yang durhaka dan bagaimana menghormati kedua orang tua. Seperti yang terdapat dalam kutipan berikut:

"Nenek menceritakan masa lalu kepada Fatwa usai melaksanakan sholat ashar dan zuhur. Biasanya nenek akan menjemput Fatwa kerumahnya untuk menemani beliau. Ia terlihat begitu memahami makna cerita yang baru saja ia dengar dari neneknya. Tak berkedip sedikit mata polosnya saat menunggu kalimat demi kalimat yang terlontar dari mulut nenek. Nanti kalau sudah besar Fatwa tidak boleh dongkol sama Ama, ya Nak?Apapunyang Ama suruh lakukan,! jangan menolak, jangan berkata tidak,! Ridho Allah tergantung pada orang tua. Jika hati orang tua terluka karena sikap kita, maka Allah akan menutup pintu hati kita. Jadilah anak yang patuh dan menurut pada orang tua. Jika Fatwa melawan, nanti dibawa dewa.”(Amika An, 2014: 34).

Berdasarkan kutipan di atas, tindakan yang dilakukan oleh tokoh Nenek merupakan nilai kepedulian dan kasih sayang. Nilai tersebut dilihat dari tindakan tokoh Nenek menceritakan masa lalunya, kepada cucunya yaitu Fatwa tentang cerita Anak Dewa. Tujuan nenek menceritakan cerita tersebut agar cucunya bisa menghotmati dan patuh kepada orang tuanya dengan memberikan contoh tentang cerita rakyat. Begitu cara tokoh nenek memberikan nilai kepedulian dan kasih sayang dengan cara menceritakan kisah masa lalunya agar cucunya tersebut dapat mengambil hikmah dari cerita tersebut. Tokoh nenek selain menceritakan kisah yang ia alami ia juga bercerita tentang cerita tentang Batu ampa dan Batu Jawi. Seperti yang terdapat pada kutipan berikut:

"Semoga ke depannya tidak akan ada lagi manusia-manusia selanjutnya dikutuk menjadi batu. Berjalan lah pada rel yang benar, kawan! Cukuplah doa orang tua menjelma menjadi pengiring keberhasilan kita. Bukan doa-doa murka yang tampa sengaja terlontar ketika hati mereka terluka, niscaya, jika Allah berkata kun, maka jadilah apa yang Allah kehendaki. Fa'tabiru yaa ulil absha, maka ambillah pelajaran oleh orang-orang yang berfikir. Allah senantiasa menyuruh kita mengambil pelajaran dari kaum-kaum terdahulu."(Amika An. 2014:74).

Kutipan di atas pengarang menggambarkan bahwa tokoh Nenek menceritakan cerita kedurhakaan anak kepada orang tuanya yaitu batu Jawi dan Batu Hampa. Tokoh nenek menjelaskan tentang cerita Batu ampa dan Batu Jawi. Dari cerita tersebut dapat diambil pelajaran agar tidak ada lagi manusia-manusia yang terkutuk atau yang durhaka kepada orang tuanya. Cukup cerita rakyat dijadikan sebagai aset budaya yang harus dijaga.

"Setiap hari, ba'da magrib nenek selalu datang ke rumah melihat kemajuan-kemajuan yang dari hari berusaha ditingkatkan sang cucu. Begitupun halnya dengan mamak-mamak dan Uda Buyuang yang selalu menyempatkan diri menghampirinya setiap hari.”(Amika An, 2014: 168). 
Berdasarkan kutipan di atas, tindakan yang dilakukan oleh tokoh Nenek merupakan nilai kepedulian dan kasih sayang. Nilai tersebut dilihat dari tindakan yang dilakukan oleh Nenek kepada Fatwa. Ia selalu memperhatikan kemajuan-kemajuan cucunya dan selalu menyempatkan dirinya untuk datang kerumah cucunya . Selain tokoh nenek dan mamak, nilai kepedulian dan kasih sayang disampaikan melalui tokoh Buyuang dan kawan-kawanya, seperti yang terlihat pada kutipan di bawah ini.

"Terkadang Buyuang dimintai tolong oleh ama Fatwa untuk menjaganya. Bocah penurut itu juga gemar bermain dengan anak kecil. Pandai sekali Ia bercengkrama dengan anak-anak yang lebih muda darinya. Bahkan ketika Fatwa buang air kecil Buyuang tidak jijik mengganti celananya. Cara bermain Fatwa berbeda dengan anak-anak kebanyakan, jika anak-anak lain bermain sambil mengajarkan lagu-lagu Bu Kasur dan T-Bob, Buyuang mengajarkan lagu-lagu nasyid yang berisi huruf-huruf hijaiya, nama-nama nabi dan nama-nama malaikat” (Amika An, 2014:19).

Selain tokoh Mak tuo nilai kepedulian dan kasih sayang, nilai tersebut juga disampaikan melalui tokoh Ama. Terlihat dari tindakan tokoh Ama kepada anaknya yaitu tokoh Fatwa. ketika Fatwa masih kecil Ama begitu telaten dan dengan penuh kepedulian Ama merawat Fatwa yang selalu mengusap-usap kepala anaknya. Seperti pada kutipan di bawah ini.

"Astafirullah, sayang... maafin ama ssst ssst ssst.. mana yang sakit, nak? Tanyanya sambil mengelus-elus kepala anaknya" (Amika An, 2014:24).

"Perempuan itu tak henti mengelus dan mencium bayinya. Berulangkali ia mencoba menyusui tapi tangis anaknya tak kunjung reda. Diusapnya kepala buah hatinya sembari melantunkan ayat-ayat Allah.” (Amika An, 2014:25).

"Ama tidak akan membiarkan siapapun merendahkan mu. Kamu tetap anak Ama, sebelum ataupu sesudah kebakaran itu. Walaupun sekarang perubahan itu sudah nyata, tapi kamu sama dengan anakanak lainya. Kekurangan mu saat ini adalah kelebihanmu nanti.”(Amika An, 2014:142).

Di sisi lain, nilai kepedulian dan kasih juga disampaikan melalui tokoh anak-anak di surau yang peduli sesamanya. Tanpa disuruh mereka segera membantu gurunya menggulung tikar di surau. Sebagaimana yang terdapat dalam kutipan berikut.

"Jam setengah tiga belum banyak anak-anak yang hadir sekita rdua atau empat orang. Spontan mereka berinisiatif membantu uwo mangguluang lapiak. Tergopoh-gopoh mereka mengangkat gulungan tikar dan karpet untuk diketepikan menuju bagian sudut"(Amika An, 2014:103).

Sementara itu sikap kepedulian juga tergambar pada orang-orang terdekat Fatwa, ketika Fatwa berada di rumah sakit. Mereka begitu cemas dan peduli akan keselamatan diri Fatwa. Seperti yang terdapat dalam kutipan berikut:

"Fatwa, cepat sembuh ya dik! Ini uda bawaka makanan kesukaan Fatwa. Bujuk Buyuang walaupun sakit, masih bisa sholatkan? Tanya Nanang. Alhamdullah tetap, da. Kata mak tuo, kita harus melaksanakan sholat dalam keadaan apapun. Jika tidak bisa berdiri, maka duduk. Jika tidak bisa duduk maka berbaring, jika masih tidak cukup kedipan mata"(Amika An, 2014:137). 
Sikap kepedulian juga disampaikan melalui tokoh mamak. Nilai tersebut dapat dilihat dari tindakan tokoh Mamak yang kepedulian, kepada keponakan yaitu Fatwa. Ia pun ikut serta dalam keberangkatan Fatwa untuk citacitanya. Pada kutipan di bawah ini menggambarkan bahwa mereka begitu peduli dan sayang terhadap Fatwa.

\begin{abstract}
"Sebelum keberangkatannya ke Aro Suka, mamak-mamaknya berkumpul di rumah, memberinya uang, mereka bilang sebagai bekal membeli kue. Musyawaroh tak pernah lepas dari setiap keputusan. Termasuk ketika dia akan jauhdari mereka hanya untuk beberapa hari. Fatwa tidak bisa menuliskannya dengan angka betapa besar rasa ssyang mereka padanya. Tak ada satuan dan tak ada alat hitung untuk menyatukannya" (Amika An,2014:201).
\end{abstract}

"Selama di Aro Suka, pada waktu-waktu istirahat mereka akan menghubungi Fatwa lewat Da Taufiq. Selebihnya kan diikuti dengan petuah-petuah panjang lebar agar Fatwa menjaga diri”(Amika An, 2014:201).

Berdasarkan uraian di atas dapat disimpulkan bahwa nilai kepedulian dan nilai kasih sayang dimiliki oleh tokoh Ama, Nenek, Mamaknya, Teman-teman Fatwa dan orang-orang terdekat Fatwa.

\title{
NILAI CINTA DAMAI
}

Cinta damai ialah tidak menginginkan pertengkaran, mencintai persatuan dan persaudaraan. Dalam novel Kutub Tak Bersaju nilai cinta damai disampaikan melalui tindakan yang dilakukan oleh tokoh Angku. Ini terlihat pada kutipan berikut.

"Bukan karena orang kampung tidak paham hukum, bukan karena tidak sanggup membayar pengacara tapi angku menjawab dengan alasan yang cukup logis. Aku hanya ingin kesadarannya saja. Jika dia orang yang beragama, tentu dia akan takut sanksi akhirat dari pada sanksi dunia, jawab angku penuh wibawa"(Amika An, 2014:48).

Berdasarkan kutipan di atas, tindakan yang lakukan oleh tokoh Angku merupakan nilai cinta damai. Nilai tersebut dapat dilihat dari perilaku tokoh Angku yang tidak ingin memperbesar masalah karena tokoh Angku tahu itu hanya kehidupan di dunia. Beliau yang tidak ingin memperselisihkan dan tak ingin bertengkar gara-gara harta bahkan beliau memilih rela untuk melepas harta karena beliau percaya akan hukum Allah yang adil.

\section{NILAI SOPAN SANTUN DAN TAAT PADA ORANG TUA}

Nilai sopan santun dan taat pada orang tua juga terdapat pada novel Kutub Tak Bersaju, nilai tersebut disampaikan melalui tindakan tokoh Ama yang sering mengajarkan sifat sopan santun kepada orang tua dan sesama, sebagaimana yang terdapat pada kutipan di bawah ini.

"Nanti kalau sudah besar, Fatwa tidak boleh dongkol sama Ama ya nak. Apapun yang ama suruh lakukan, jangan menolak, jangan berkata tidak! Rhido Allah tergantung rhido orang tua. Jika hati orang tua terluka karena sikap kita, maka Allah akan menutup pintu hati kita. Jadilah anak yang patuh dan penurut kepada orang tua."(Amika An, 2014:34).

Kutipan di atas, tindakan yang dilakukan oleh tokoh Ama merupakan nilai sopan santun. Nilai tersebut dapat dilihat dari tindakan tokoh Ama dalam mengajarkan anaknya yang tidak lupa mengajarkan nilai sopan santun dan 
taat pada kedua orang tua kepada tokoh Fatwa. Ama selalu mengingatkan kepada Fatwa bahwa nanti Fatwa sudah besar, Fatwa harus menjadi anak yang patuh dan penurut kepada kedua orang tua dan jangan pernah membantah kata orang tua. Nilai sopan santun dan taat pada orang tua disampai melalui tokoh Buyuang. Sebagaimana yang terdapat pada kutipan di bawah ini.

"Buyuang kecil harus menggantikan peran ayahnya karakternya terbentuk dengan mantap, ilmu agama yang dipelajari begitu dia amalkan. Bekerja tak kenal lelah, disuruh tak pernah tidak, dinasehati dia menurut, berjualan apa saja dia mau. Upah tak terlalau jadi masalah.”(Amika An, 2014:22).

Pada kutipan di atas, tindakan yang dilakukan oleh tokoh Buyuang merupakan nilai sopan santun dan taat pada orang tua. Nilai tersebut dapat dilihat dari tindakan Buyuang yang tidak pernah lelah dan menyerah serta tidak pernah menolak permintaan tolong orang lain dan selalu menerima nasehat. Nilai sopan santun dan taat pada orang tua disampaikan melalui tokoh Fatwa. Seperti yang terdapat kutipan beriku:

"Wa, jaga adik ya! Ama mau mencuci dulu."

"Iya, Ma."

“Ini tugas yang paling digemari Fatwa.”(Amika An, 2014: 169).

Berdasarkan kutipan di atas. Tindakan yang dilakukan oleh tokoh Fatwa merupakan nilai taat kepada orang tua. Nilai tersebut dapat dilihat dari prilaku tokoh Fatwa yang tidak mengatakan tidak bila kedua orang meminta tolong.

\section{NILAI MENOLONG SESAMA}

Menolong sesama merupakan saling membantu antar sesama manusia. Membantu tanpa mengharapkan imbalan. Sebuah tindakan yang melibatkan orang lain karena manusia adalah makhluk sosial yang tidak bisa hidup sendiri. Nilai menolong sesama juga terdapat pada novel Kutub Tak Bersalju, nilai tersebut disampaikan melalui tindakan dan perilaku tokoh seperti seorang tokoh melakukan kegiatan ketika datang suatu acara, ini terlihat sebagaimana yang terdapat pada kutipan di bawah ini.

"Etek-etek sabalah rumah datang tanpa menunggu panggilan. Mereka datang untuk memasak penganan pada saat mambadak nanti. Berbagai celoteh dari cerita memecah asap suasananya akrab" (Amika An, 2014:13).

Dari kutipan di atas menggambarkan nilai menolong sesama. Ini terlihat pada kedatangan etek-etek ke rumah Fatwa tanpa diundang untuk membantu memasak, semua itu dilakukan karena rasa menolong sesama.Selain itu nilai menolong sesama juga terdapat anak-anak di surau. Seperti kutipan berikut.

"Jam setengah tiga belum banyak anak-anak yang hadir, sekitar dua atau empat orang. Spontan mereka berinisiatif membantu Uwomengguluang lapiek. Tergopoh-gopoh mereka mengakat gulungan tikar dan karpet untuk diketepikan menuju bagian sudut.”(Amika An, 2014: 103).

Kutipan di atas, tindakan yang dilakukan oleh anak-anak surau merupakan nilai menolong sesama. Nilai tersebut dapat dilihat dari prilaku anak-anak surau tanpa di suruh mereka membantu tokoh Uwo. 


\section{NILAI KESABARAN}

Nilai kesabaran adalah ketenangan hati dalam menghadapi cobaan. Nilai kesabaran juga terdapat dalam novel

Kutub Tak Bersalju. Nilai kesabaran disampaikan melalui tokoh Pak Layu ini terlihat pada kutipan di bawah ini .

"Dengan sabar Pak Layu mengarahkan dan mengajarkan cara sholat. Mengingatkan sehelai rambutnya tak boleh keluar, melihat kesana kemari, berbicara merupakan hal-hal yang tidak boleh dilakukan ketika shalat."(Amika An, 2014: 104).

Kutipan di atas, tindakan yang dilakukan oleh tokoh Pak Layu merupakan nilai kesabaran. Nilai tersebut dapat dilihat dari tindakkan yang dilakukan oleh tokoh Pak Layu dalam mengarahkan dan mengajarkan cara salat kepada anak-anak di surau. Nilai kesabaran juga disampaikan melalui tokoh Fatwa. Seperti yang terdapat dalam kutipan berikut.

"Balasan kali dia berteriak, jawaban yang sama sabar ya nak. Selalu itu yang terdengar. Jelas bukan suara Ama, Nenek, ataupun Abak, orang itu mengusap rambut ikalnya, tak selembut usapan Ama. Saat Fatwa melihat wajahnya, gelap. Dia tak berbentuk."(Amika An, 2014:135).

Kutipan di atas menggambarkan bahwa tokoh Fatwa memiliki nilai kesabaran. Ia harus sabar atas peristiwa kebakaran yang menimpanya. Selain itu tokoh Fatwa harus bersabar dalam menghafal alquran karena tanpa melihat Fatwa hanya mendengarkan tangisan suara adiknya saja. Seperti yang terdapat dalam kutipan berikut:

"Dia harus banyak bersabar. Untuk sementara, cukup sulit, telinga, dan suaranya yang bisa mengenal Naumi. Matanya harus berpuasa."(Amika An, 2014: 169)

"Da, pengumuman juara jam berapa?"

"Hehehe.Tidak sabaran sekali. Setelah semua cabang selesai, pengumunanya akan segera dilakukan, Dik."

"Kira-kira jam berapa, Da?

“Sabar. Mungkin ba’da Maghrib.”(Amika An, 2014: 196).

Berdasarkan kutipan di atas, tindakan yang dilakukan oleh tokoh Fatwa merupakan nilai kesabaran. Nilai tersebut dapat dilihat dari perilaku tokoh Fatwa yang sabar menghadapi cobaan dan harus harus sabar menunggu hasil perlombaannya dan nilai kesabaran ini terlihat ketika tokoh Fatwa tidak sabar menunggu hasil perlombaannya, tokoh Da Taufik menyuruh Fatwa untuk sabar menunggu hasilnya.

\section{NILAI MENGHARGAI PRESTASI}

Menghargai dapat dilakukan dengan memberikan penghargaan, hadiah, mengucapkan selamat dan lain sebagainya. Hal ini bertujuan agar orang tersebut merasa senang. Selain itu juga bertujuan untuk memberikan semangat dan dukungan terhadapnya agar terus mempertahankan prestasinya. Dalam karya sastra juga terdapat bentuk perilaku menghargai prestasi. Seperti yang terdapat dalam novel Kutub Tak Bersalju karya Amika An. Nilai tersebut disampaikan melalui orang-orang terdekat Fatwa yang menghargai prestasi Fatwa yang selalu memberikan dukungan terhadap Fatwa. Tidak hanya itu, bahkan bapak Gubernur juga memberikan apresiasinya dan penghargaan kepada Fatwa. seperti yang terdapat dalam kutipan berikut:

"Dan yang paling mencengangkan dari tutur kata adalah penghargaan yang sebesar-sebesarnya beliau tujukan kepada gadis berusia tujuh tahun, Fatwa Tauqan yang telah berjasa membesarkan 
nama Sumantra Barat. Beliau ingin berkomunikasi secara langsung dengan anak buta dengan kegigihan luar biasa itu.“(Amika An, 2014: 221).

"Acara beranjak pada sambutan gubernur. Beliau begitu mengapresiasi kesigapan masyarakat Danau Kembar. Beliau juga memberikan bantuan guna perbaikan pembangunan Mesjid Firdaus dan yang paling mencengangkan dari tutur kata beliau adalah penghargaan yang sebesar-sebesarnya beliau tunjukan kepada gadis yang berusia tujuh tahun. Fatwa Tauqan yang telah berjasa membesarkan nama Sumatra Barat. Beliau ingin berkomunikasi secara langsung dengan anak buta dengan kegigihan luar biar itu. Beliau memintanya berjalan mendekat. Beliau mengusap kepalanya"( Amikan An, 2014: 221).

Berdasarkan uraian di atas maka dapat disimpulkan dalam novel Kutub Tak Bersalju karya Amika An. Terdapat nilai didaktis atau pendidikan adalah nilai tauhid yaitu nilai keimanan dan ketakwaan, kegigihan dan keuletan, kerja keras dan mandiri, kesabaran, saling menolong, kepedulian dan kasih sayang, cinta damai, sopan santun dan taat pada orang tua, kerja sama, menghargai prestasi. Nilai-nilai tersebut dapat memberikan manfaat bagi pembaca.

\section{PENUTUP}

Berdasarkan hasil pembahasan, dapat penulis simpulkan dalam novel Kutub Tak Bersalju karya Amika An terdapat tokoh Fatwa sebagai tokoh utama. Sementara tokoh tambahan terdiri dari tokoh Ama, Abak, Nenek, Mak Tuo, Mamak-Mamaknya Fatwa, Uda Taufik, Buyuang, Beni dan Uni Maulana. Tokoh Fatwa diceritakan seorang gadis kecil yang berumur tujuh tahun yang memiliki kekurangan fisik yaitu tuna netra. Meskipun ia buta tapi itu tidak menjadi penghalang baginya untuk menjadi penghafal alquran. Tokoh Fatwa memiliki semangat dalam menghafal alquran hingga membuahkan hasil sebagai seorang hafidzah. Ia sangat gigih dalam mewujudkan citacitanya menjadi hafidzah. Sehingga ia mampu menyemangati dan menunjukkan pada orang-orang di sekitarnya bahwa kekurangan fisik bukanlah hambatan untuk mewujudkan impian. Selain itu, tokoh Fatwa juga memiliki tekad yang kuat dan memiliki sifat keberanian terhadap hal-hal membahayakan dirinya. Ia terus berjalan menuju surau dengan kebutaannya. Bahkan sering terperanjat dengan klakson mobil pada saat menyeberang jalan. Namun pada akhirnya ia tetap sampai ke surau tempatnya belajar. Tidak hanya menjadi seorang hafizah, tokoh Fatwa juga berkeinginan untuk melanjutkan perjuang menjadi seorang qoriah walaupun dengan fisiknya yang terbatas. Jadi, dapat disimpulkan bahwa tokoh Fatwa merupakan tokoh yang sabar, tegar, gigih, penyayang, pemberani, pantang menyerah, tidak mudah putus asa, rajin belajar, ulet dan tekun, mudah menerima nasehat, serta mempunyai keinginan yang kuat.

Nilai didaktis yang terdapat dalam novel Kutub Tak Bersalju karya Amika An adalah nilai tauhid yaitu nilai keimanan dan ketakwaan, kegigihan dan keuletan, kerja keras dan mandiri, kepedulian dan kasih sayang, kesabaran, cinta damai, sopan santun dan taat pada orang tua, saling menolong, menghargai prestasi, selain itu juga terdapat nilai kearifan lokal. Nilai-nilai tersebut dapat memberikan manfaat bagi pembaca.

\section{REFERENSI}

An, Amika. 2014. Kutub Tak Bersalju. Depok: Indie Publishing.

Ahmad, Abu dan Nur Uhbiyati. 1991. Ilmu Pendidikan. Jakarta: PT Rineka Cipta. 
Bertens, K. 2001. Etika. Jakarta: Pustaka Utama.

Departemen Pendidikan Nasional. 2002. Kamus Besar Bahasa Indonesia. Edisi keempat. Jakarta: Balai Pustaka.

Endraswara, Suwardi. 2011. Metodologi Penelitian Sastra: Epistemologi, Model, Teori, dan Aplikasi. Yogyakarta: CAPS.

Fananie, Zainuddin. 2011. Pedoman Pendidikan Modern. Solo: PT Tiga Serangkai Pustaka Mandiri.

Herimanto. 2016. Ilmu Sosial \& Budaya Dasar. Jakarta: Bumi Aksara.

Hanani, Silfia. 2002. Surau. Bandung: Humaniora Utama Press(HUP).

Haya, Asra. 2015. Nilai-Nilai Didaktis Dalam Cerita Anak Harian Kompas 2013”. (Skripsi). Padang: Jurusan Sastra Indonesia Fakultas Ilmu Budaya Universitas Andalas.

Izharman, 2014. Pendidikan Agama Islam Pembentukana Kepribadian Islami. BPKM.

Kurniawan, Heru. 2009. Sastra Anak dalam Kajian Strukturalisme, Sosiolog, Semiotika, Hingga Penulisan Kreatif. Yogyakarta: Graha Ilmu.

Mashita, Mutia. 2013. Nilai-Nilai Pendidikan dalam novel Sepatu Dahlan Khrisna Pabichara. Diakses pada tanggal 15 Juli 2018, pada pukul 20:45 Wib.

Muslich, Masnur. 2011. Pendidikan Karakter: Menjawab Tantangan Krisis Multidimensional. Jakarta: PT Bumi Aksara.

Nurgiyantoro, Burhan. 1995. Teori Pengkajian Fiksi. Yogyakarta. Gadjah Mada University Press.

Pradopo, Djoko Rahmat. 1994. Prinsip-prinsip Kritik Sastra. Gadjah Mada University Press.

Ratna, Nyoman Kutha. 2004. Teori, Metode dan Teknik Penelitian Sastra. Yogyakarta: Pustaka Pelajar.

Suriasumantri, Jujun S. 2006. Ilmu Dalam Prespektif Sebuah Karangan Tentang Hakekat Ilmu. Jakarta: Yayasan Obor Indonesia.

Sudjiman, Panuti. 1992: Memahami Cerita Rekaan. Bandung: Pustaka Jaya.

Semi, Atar. 1984. Anatomi Sastra. Padang: FPBS IKIP.

Suryani, Yuli Fitria. 2006. "Nilai-nilai Didaktis Dalam Cerita Anak Di Surat kabar Singgalang Minggu”(Skripsi). Padang: Jurusan Sastra Indonesia Fakultas Ilmu Budaya Universitas Andalas.

Sonata, dkk. 2014.Tinjauan structural dan Nilai Pendidikan dalam Novel Bidadari Surga karya Tere Liye. Diakses pada tanggal 15 Juli 2018, pada pukul 21:15Wib

Sepniyantika, Rice. 2012. "Nilai-Nilai Didaktis Dalam Novel Cinta Suci Zahrana Karya Habiburahman El Shirazy.”(Skripsi). Padang:Jurusan Sastra Indonesia Fakultas Ilmu Budaya Universitas Andalas.

Wellek dan Warren.1990, Teori Kesusastraan. Jakarta: Gramedia. 